\title{
PENGUKURAN EFISIENSI DAN PRODUKTIVITAS RUMAH ZAKAT INDONESIA DENGAN METODE INDEKS MALMQUIST ${ }^{1}$
}

\author{
Fahrizal Rizky Putra Pratama \\ Departemen Ekonomi Syariah-Fakultas Ekonomi dan Bisnis-Universitas Airlangga \\ Email: gidregal@gmail.com

\section{Eko Fajar Cahyono} \\ Departemen Ekonomi Syariah-Fakultas Ekonomi dan Bisnis-Universitas Airlangga \\ Email: ekofajarc@feb.unair.ac.id
}

\begin{abstract}
:
The results obtained from the Malmquist Productivity Index seen from the TFP Change score indicate Rumah Zakat Indonesia has an increase in productivity from 2010 to 2017. This was added to the score of more than 1,000 in 2014 and 2015. In carrying out its functions as a manager of zakat, improving the performance of Rumah Zakat in Indonesia in its early years the beginning of its formation has not been $100 \%$ efficient in carrying out its functions, but fulfilling the time of Rumah Zakat has been able to activate its functions efficiently. Evidenced by the last 3 years Rumah Zakat has an efficiency level of 100\% and shows Rumah Zakat is an National Amil Zakat Institution (LAZNAS) which has an efficient performance.
\end{abstract}

Keywords: Malmquist, Rumah Zakat, Efficient, Productivity

I. PENDAHULUAN

LAZ (Lembaga Amil Zakat) merupakan salah satu lembaga yang berperan dalam pelaksanaan, pengumpulan, dan pendistribusian zakat di Indonesia.Lembaga pengelola zakat di Indonesia mengalami perubahan dari waktu ke waktu.Perubahan itu terutama dipengaruhi oleh kebijakan pemerintah yang berlaku. Secara umum, kebijakan pemerintah dalam urusan zakat menunjukkan perbaikan dan peningkatan yang diharapkan agar setiap perubahan akan menjadi semakin terorganisir dan memiliki jangkauan secara nasional.

Zakat merupakan perintah Allah SWT yang diwajibkan kepada orangorang yang beriman dan mampu atas harta yang mereka miliki yang tentunya telah mencapai nishab yang ditentukan syara' bertujuan semata-mata untuk mensucikan diri dan harta mereka yang dapat disalurkan ke alokasi-alokasi yang telah ditetapkan dalam Al-qur'an:

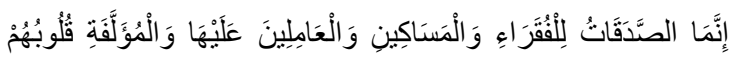

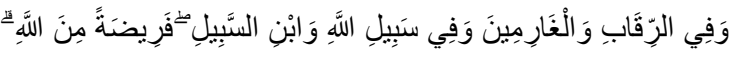

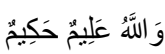

"Sesungguhnya zakat-zakat itu hanya untuk orang-orang faqir,orang-orang miskin, amil, para muallaf yang dibujuk hatinya,orang-orang yang berutang, untuk jalan Allah dan orang-orang yang sedang dalam perjalanan, sebagai suatu ketetapan yang diwajibkan Allah; dan Allah Maha Mengetahui dan Maha Bijaksana." (At-taubah: 60)

Berdasarkan data yang dikeluarkan oleh BPS Pusat jumlah penduduk muslim di Indonesia sebanyak 207.176.162 orang. Data tersebut

\footnotetext{
${ }^{1}$ Jurnal ini merupakan bagian dari skripsi Fahrizal Rizky Putra Pratama, NIM: 041211431010 , yang diuji pada tanggal 18 Januari 2019.
} 
menunjukkan bahwa mayoritas penduduk di Indonesia beragama Islam. Karena zakat merupakan kewajiban bagi setiap orang islam maka otomatis potensi zakat di Indonesia termasuk cukup melimpah dilihat dari presentase jumlah penduduk yang beragama islam.

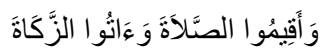

"Dan tegakkanlah shalat dan tunaikanlah zakat" (Al Baqarah:110).

Memang secara logika manusia, dengan membayar zakat maka harta kita akan berkurang. Jika kita mempunyai penghasilan Rp 2 juta, misalnya, maka zakat yang kita keluarkan adalah 2,5 persen dari Rp 2 juta, yaitu Rp 50.000. Jika kita melihat menurut logika manusia, harta yang pada mulanya berjumlah Rp 2 juta kemudian dikeluarkan $\mathrm{Rp} 50.000$, maka harta kita menjadi Rp 1,95 juta, yang berarti jumlah harta kita berkurang. Tapi, menurut ilmu Allah yang Maha Pemberi Rezeki, zakat yang kita keluarkan tidak mengurangi harta kita, bahkan menambah harta kita dengan berlipat ganda. Allah SWT berfirman dalam Surat Ar-Rum Ayat 39:

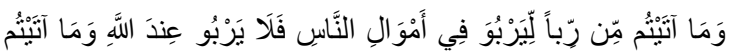

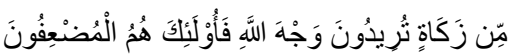

"Dan sesuatu riba yang kamu berikan agar dia bertambah pada harta manusia, maka riba itu tidak menambah pada sisi Allah. Dan apa yang kamu berikan berupa zakat yang kamu maksudkan untuk mencapai keridaan Allah, maka itulah orang-orang yang melipat gandakan.
Dalam dunia pengukuran efisiensi, saat ini banyak dikenal pendekatan Data Evelopment Analysis (DEA).DEA merupakan suatu alat yang dapat digunakan untuk mengukur dan membandingkan kinerja sejumlah unit pelayanan atau bisnis, industri keuangan, rumah sakit bahkan lembaga pendidikan.DEA juga dapat menunjukkan spesifikasi ketidakefisienan unit pelayanan tersebut.

Sejak adanya metode DEA yang pertama kali diperkenalkan oleh Charnes. Cooper dan Rhodes pada 1978, para peneliti di sejumlah bidang menyadari bahwa DEA merupakan metodologi yang sangat baik dan relative mudah digunakan dalam proses pemodelan operasional untuk evaluasi kerja. Dalam penelitian ini, DEA digunakan sebagai alat untuk mengukur dan membandingkan kinerja lembaga amil zakat (LAZ) dalam hal ini seluruh lembaga amil zakat (LAZ) di Indonesia.

Lebih jauh, untuk mengukur produktivitas lembaga amil zakat (LAZ) yang diobservasi, penelitian ini menggunakan analisis Malmquist Index (MPI). Indeks Malmquist merupakan bagian dari metode DEA yang secara spesifik melihat tingkat produktivitas masing-masing unit bisnis, sehingga akan terlihat perubahan dari tingkat efisiensi dan teknologi yang digunakan berdasarkan input dan output yang telah ditetapkan. Indeks Malmquist juga 
digunakan untuk menganalisis perubahan kinerja antar waktu.

\section{LANDASAN TEORI}

Efisiensi dan produktivitas merupakan konsep yang menunjukkan rasio hasil perbandingan antara input dan output. Kedua rasio tersebut menunjukkan bahwa efisiensi dan produktivitas dapat dikendalikan dengan jalan merekayasa pengelolaan input dan output, atau bahkan keduanya sekaligus. Efisiensi dan produktivitas dapat digunakan untuk mengukur kinerja suatu unit kegiatan ekonomi.

Menurut Malayu (2003) bahwa efisiensi adalah perbandingan yang terbaik antara input (masukan) dan output (hasil antara keuntungan dengan sumber-sumber yang dipergunakan), seperti halnya juga hasil optimal yang dicapai dengan penggunaan sumber yang terbatas. Dengan kata lain hubungan antara apa yang telah diselesaikan. Sedangkan pendapat Halim (2004) yang menjelaskan bahwa efisiensi adalah pengukur besarnya biaya pemungutan yang digunakan terhadap realisasi penerimaan.

Sebuah manajemen yang efisien (efficient operation) akan menggunakan sumber daya yang ada secara optimal demi mencapai tujuan yang diinginkan secara maksimal, dan tidak membuangbuang sumber daya yang ada secara cuma-cuma dalam melaksanakan operasinya. Suatu operasi tidak efisien jika sebuah manajemen menggunakan sumber daya melebihi dari jumlah yang diperlukan.

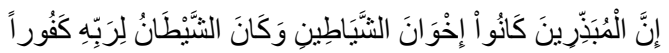

"Sesungguhnya orang-orang pemboros itu adalah saudara-saudara setan) artinya berjalan pada jalan setan (dan setan itu adalah sangat ingkar kepada Rabbnya) sangat ingkar kepada nikmat-nikmat yang dilimpahkan oleh-Nya, maka demikian pula saudara setan yaitu orang yang pemboros" (QS AL-Israa' : 27).

Pengelolaan zakat merupakan kegiatan pengelolaan, pengawasan dan pendistribusian terhapad zakat serta melakukan pendayagunan terhadap zakat. Sednagkan menurut sumber lain zakat adalah harta yang wajib disisihkan oleh seseorang muslim atau badan hukumyang di miliki oleh seorang muslim sesuai dengan ketentuan agama diberikan kepada yang berhak menerimanya jadi, dalam pengelolaan zakat dapat dipikirkan cara-cara pelaksanaanya dengan ilmu pengetahuan yang sesuai dengan tujuan zakat iyalah meningkatkan taraf hidup anggota masyarakat yang lemah ekonomi dan mempercepat kemajuan agama islam menuju tercapainya masyarakat yang adil, maju dan makmur diridhoi oleh allah SWT.

Indeks Malmquist pertama dibuat oleh Sten Malmquist pada 1953 untuk mengukur produktivitas.Namun dalam perkembangannya, Malmquist Index (Mizobuchi, 2015).Ada dua hal yang dihitung dalam pengukuran indeks 
Malmquist yaitu efek catch-up dan efek frontier shift.Efek catch-up mengukur tingkat perubahan relative dari periode 1 ke periode 2. Sementara itu efek frontier shift mengukur tingkat perubahan teknologi yang merupakan kombinasi input dan output dari periode 1 ke periode 2. Efek frontier shift sering juga disebut dengan sebutan efek inovasi.

Indeks Malquist merupakan indeks bilateral yang digunakan untuk membandingkan teknologi dua unsur ekonomi. Indeks Malmquist berlandaskan pada konsep fungsi produksi (production function) yang mengukur fungsi produksi maksimum dengan batasan input yang sudah ditentukan. Dalam perhitungannya, indeks ini terdiri dari atas beberapa hasil yaitu : efficiency change, technological change, pure efficiency change, economic scale change dan TFP change.

DEA adalah sebuah metode optimasi program matematika yang dipergunakan untuk mengukur efisiensi teknis suatu unit kegiatan ekonomi (UKE) dan membandingkan secara relatif terhadap UKE lain (Amanda, 2010).

Fase pertama penggunaan metode DEA diprakarsai (Farrel, 1957 dalam Sunarto, 2010) untuk membandingkan efisiensi relatif dengan sampel petani secara cross section dan terbatas pada satu output yang dihasilkan oleh masing-masing unit sampel. Dalam perkembangannya, DEA adalah sebuah alat analisis yang digunakan untuk mengukur efisiensi relatif dalam penelitian pendidikan, kesehatan, transportasi, pabrik, maupun perbankan (Amanda, 2010).

\section{METODE PENELITIAN}

\section{Pendekatan Penelitian}

Penelitian ini menggunakan metode kuantitatif dengan analisis Indeks Malmquist dan aplikasi metode DEA Dual Programing. Objek penelitiannya adalah Lembaga Amil Zakat (LAZ) Rumah Zakat tahun 2018 .Dalam penelitihan ini, estimasi perubahan TFP (Total Factor Productivity) serta komponen - komponennya mengacu pada Malmquist Index dan aplikasi metode DEA Dual Programing. Indeks perubahan TFP Malmquist terbentuk dari nilai efficiency change dan technology change. Melalui nilai efficiency change akan diketahui apakah terjadi perubahan tingkat efisiensi. Sedangkan technology change menunjukkan apakah terjadi perubahan batas teknis.

\section{Identifikasi Variabel}

Menurut Sugiyono (2009), variabel adalah suatu atribut atau sifat atau nilai dari orang, obyek, atau kegiatan yang mempunyai variasi tertentu yang ditetapkan oleh peneliti untuk dipelajari dan kemudian ditarik kesimpulannya. Variabel input dan output digunakan mengukur efisiensi dan tingkat produktivitas Lembaga Amil Zakat (LAZ). Sebagai variable input adalah Biaya Personalia (X1), Biaya Operasional (X2), Biaya Sosialisasi (X3). Sedangkan untuk variabel output yaitu ZISWAF yang 
terkumpul (Y1), ZISWAF yang tersalurkan (Y2).

\section{Definisi Operasional Variabel}

Definisi operasional adalah definisi yang diberikan pada suatu variabel yaitu dengan cara memberikan arti pada tiaptiap variabel atau menspesifikasikan kegiatan yang diperlukan untuk mengukur variabel tersebut (Anshori dan Iswati, 2009). Penelitian ini bertujuan untuk mengetahui terjadinya perubahan atau peningkatan efisiensi dan produktifitas pada Lembaga Amil Zakat (LAZ) Rumah Zakat. Definisi operasionalnnya sebagai berikut:

Variabel input:

1. Biaya Personalia (X1) adalah biaya yang dikeluarkan oleh Rumah Zakat untuk keperluan personal tahun 2010 2017.

2. Biaya Operasional (X2) adalah biaya yang dikeluarkan oleh Rumah Zakat untuk kepentingan operasional tahun 2010 - 2017.

3. Biaya Sosialisasi (X3) adalah biaya yang dikeluarkan oleh Rumah Zakat untuk keperluan sosialisasi di masyarakat tahun 2010 - 2017.

Variabel output:

1. ZISWAF yang terkumpul (Y1) adalah jumlah keseluruhan dana ZISWAF yang terkumpul di Rumah Zakat tahun 2010 2017.

2. ZISWAF yang tersalurkan (Y2) adalah jumlah keseluruhan dana Ziswaf yang sudah disalurkan oleh Rumah Zakat tahun $2010-2017$

\section{Jenis dan Sumber Data}

Menurut Anshori (2009) sumber data dalam penelitian adalah suatu subyek darimana data diperoleh.Data yang digunakan dalam penulisan skripsi ini meliputi Laporan Keuangan Lembaga Amil Zakat (LAZ) Rumah Zakat Indonesia tahun 2010 - 2017. Data yang digunakan dalam penulisan skripsi ini meliputi:

1. Data Sekunder

Indriantoro dan Supomo (2003) menjelaskan bahwa data sekunder pada umumnya berupa bukti, catatan atau laporan historis yang telah tersusun dalam arsip (data documenter) baik yang dipublikasikan maupun yang tidak dipublikasikan.Data sekunder dalam penelitian ini yang digunakan diperoleh melalui internet, jurnal, dan literaturliteratur lainnya yang berhubungan dengan penelitian ini.

\section{Teknik Pengumpulan Data}

Alat yang digunakan untuk mengumpulkan data dalam penelitian ini adalah Banxia Fontier Analysist 3 untuk mengukur tingkat efisiensi seluruh DMU Rumah Zakat Indonesia tahun 2018.Untuk mengukur indeks produktivitas Malmquist, software DEAP 2.1 digunakan.Selanjurnya, untuk membuat plot kuadran kelompok Lembaga Amil Zakat dengan 2 kategori (perubahan efisiensi dan perubahan faktor teknologi) pada sumbu $x$ dan sumbu $y$. 


\section{Teknik Analisis}

Teknik analisis data dalam penelitihan ini menggunakan metode indeks Malmquist.Indeks Malquist merupakan indeks bilateral yang digunakan untuk membandingkan teknologi dua unsur ekonomi. Indeks Malmquist berlandaskan pada konsep fungsi produksi (production function) yang mengukur fungsi produksi maksimum dengan batasan input yang sudah ditentukan. Dalam perhitungannya, indeks ini terdiri dari atas beberapa hasil yaitu : efficiency change, technological change, pure efficiency change, economic scale change dan TFP change (Rusydiana, 2015).

Model analisis Indeks Malmquist secara umum (Bjurek, 1996 dalam Mizobuchi, 2015) Malmquist Index didefinisikan menggunakan fungsi jarak. Adapun fungsi jarak ini dapat diklasifikasikan menjadi fungsi jarak yang berorientasi pada input dan output. Fungsi jarak input mencari ekspansi proporsional vector input yang minimal untuk vector output yang konstan. Sebaliknya, fungsi jarak output mencari ekspansi proporsional vector output yang minimal untuk vector input yang konstan. Malmquist TFP indeks mengukur perubahan TFP antar dua titik data dengan menghitung rasio jarak untuk setiap titik data tersebut, relative pada batasan teknologi. Perubahan indeks TFP Malmquist (output oriented) antara periode $t$ (periode awal) dan periode $t+1$ adalah.

$$
\begin{aligned}
& M_{0}\left(x^{t+1}, u^{t+1} ; x^{t}, u^{t}\right) \\
& =\left[\frac{D_{0}^{t}\left(x^{t+1}, \frac{u^{t+1}}{C R T S}\right)}{D_{0}^{t}\left(x^{t}, \frac{u^{t}}{C R T S}\right)} \cdot \frac{D_{0}^{t+1}\left(x^{t+1}, \frac{u^{t+1}}{C R T S}\right)}{D_{0}^{t+1}\left(x^{t}, \frac{u^{t}}{C R T S}\right)}\right]^{\frac{1}{2}} .
\end{aligned}
$$

Dimana notasi D ( $\left.U^{\prime}, x^{\prime}\right)$ mewakili jarak antara periode observasi $\dagger$ ke periode teknis S dan CRTS/constant return to scale. Bila nilai Mo lebih besar dari satu akan mengindikasikan pertumbuhan nilai TFP positif dari periode s ke periode $t$, akan tetapi jika nilainya kurang dari satu mengindikasikan penurunan TFP. Perubahan nilai Malmquist total factor productivity dapat dijabarkan ke dalam perubahan teknis dan perubahan efisiensi.

$$
\text { Perubahan Effisiensi : } \frac{D_{0}^{t}\left(x^{t+1}, \frac{u^{t+1}}{C R T S}\right)}{D_{0}^{t}\left(x^{t}, \frac{u^{t}}{C R T S}\right)} \ldots
$$

PerubahanTeknis

$:\left[\frac{D_{0}^{t}\left(x^{t+1}, u^{t+1} / C R T S\right)}{D_{0}^{t+1}\left(x^{t+1}, u^{t+1} / C R T S\right)} \cdot \frac{D_{0}^{t}\left(x^{t}, u^{t} / C R T S\right)}{D_{0}^{t+1}\left(x^{t}, u^{t} / C R T S\right)}\right]^{\frac{1}{2}}$

\section{HASIL DAN PEMBAHASAN}

Data yang digunakan dalam penelitian ini adalah data laporan keuangan Rumah Zakat dari tahun 2010 2017. Variabel input dan output didapat dari laporan keuangan Rumah Zakat dibagi menjadi tiga input dan dua output digunakan untuk mengukur efisiensi dan tingkat produktivitas Rumah Zakat. Sebagai variabel input adalah Biaya Personalia (X1), Biaya Operasional (X2), dan Biaya Sosialisasi (X3). Sementara untuk variabel output yaitu Dana ZISWAF Yang Terkumpul (Y1) dan Dana ZISWAF Yang Tersalurkan (Y2). 
Tabel 1.

Input dan Output Rumah Zakat

\begin{tabular}{lll}
\hline Variable & Definisi & Sumber \\
input & &
\end{tabular}

\begin{tabular}{lll}
\hline $\begin{array}{l}\text { Biaya } \\
\text { personalia }\end{array}$ & $\begin{array}{l}\text { Biaya untuk } \\
\text { keperluan } \\
\text { personal }\end{array}$ & $\begin{array}{l}\text { Laporan } \\
\text { keuangan }\end{array}$ \\
& & \\
Biaya & Biaya untuk & Laporan \\
operasional & $\begin{array}{l}\text { keperluan } \\
\text { operasional }\end{array}$ & \\
& & keuangan
\end{tabular}

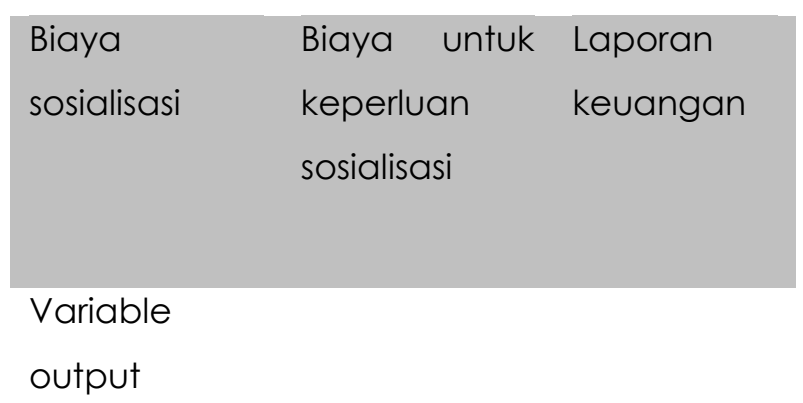

\begin{tabular}{lll} 
ZISWAF & $\begin{array}{l}\text { Jumlah } \\
\text { terkumpul }\end{array}$ & $\begin{array}{l}\text { Laporan } \\
\text { terkumpul yang }\end{array}$ \\
& & \\
& & \\
ZISWAF & Jumlah & Laporan \\
tersalur & ZISWAF yang & keuangan \\
& tersalurkan & \\
\hline
\end{tabular}

Tabel 2.

\section{Definisi Variabel Input dan Output Rumah}

\section{Zakat}

\begin{tabular}{ll}
\hline Input & Keterangan \\
\hline X1 & Biaya personalia \\
X2 & Biaya operasional
\end{tabular}

\begin{tabular}{ll}
\hline X3 & Biaya sosialisai \\
Output & \\
Y1 & ZISWAF terkumpul \\
Y2 & ZISWAF tersalur
\end{tabular}

Rumah Zakat dikelompokkan ke dalam 4 (empat) kuadran berdasarkan kategori tingkat technical change (TECH) dan kategori tingkat efficiency change (EFFCH), yakni high dan low. Kuadran 1 meliputi bulan yang memiliki technical change dan efficiency change yang tinggi, sehingga dapat dianggap sebagai bulan dimana Rumah Zakat memiliki tingkat produktivitas tinggi.

Pada sisi lain, Kuadran 4 merupakan kelompok bulan dimana Rumah Zakat memiliki tingkat technical change dan efficiency change yang rendah. Kemajuan produktivitas Rumah Zakat pada bulan - bulan tersebut dianggap memiliki tingkat kemajuan yang relatif stagnan diakibatkan nili $\mathrm{TECH}$ dan EFFCH yang kecil.

Kuadran 2 mencakup bulan dimana Rumah Zakat memiliki technical change yang tinggi, tapi di sisi lain mempunyai efficiency change yang rendah. Rumah Zakat pada bulan tersebut dapat dianggap memiliki kemampuan catching up yang rendah.Peningkatan jumlah DMU Rumah Zakat pada kuadran 2 ini menjadi tanda tidak mampunya Rumah Zakat berproduksi secara efisien.

Adapun kuadran 3 meliputi kelompok bulan dimana Rumah Zakat 
memiliki technical change yang rendah, namun disisi lain mempunyai efficiency change yang tinggi. Rumah Zakat pada bulan tersebut memiliki peningkatan teknologi produksi yang rendah, namun relatif mampu mencapai peningkatan tingkat efisiensi yang tinggi.

Tabel 3.

\section{Tingkat Produktivitas Rumah Zakat}

Indonesia

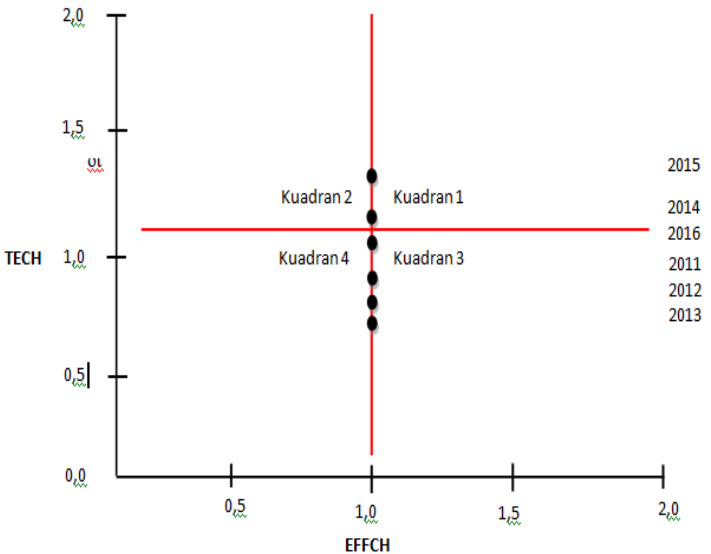

Gambar 1.

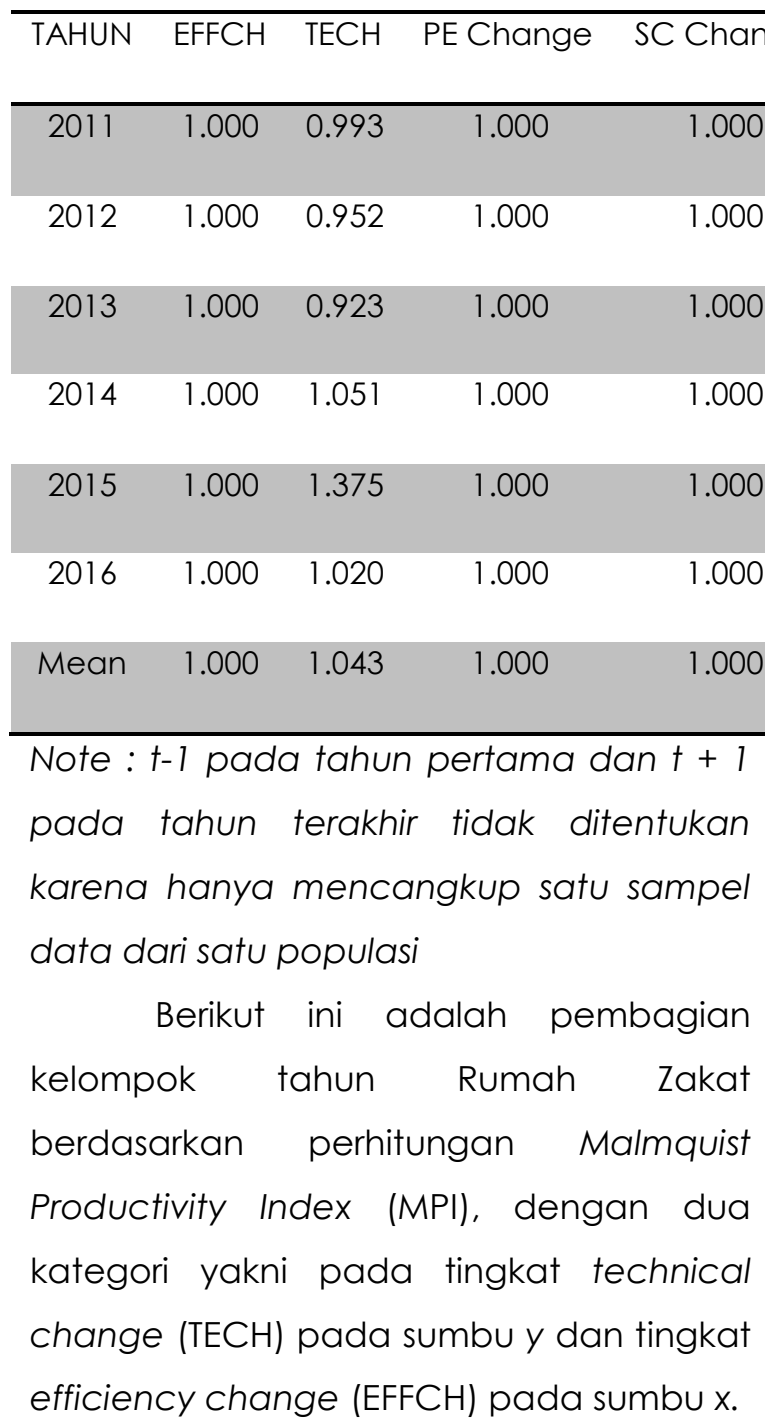


Penelitian ini mencoba menganalisis model CCR sebagai model dasar dalam DEA untuk melihat tingkat efisiensi Rumah Zakat dalam periode 2010 - 2017. Selanjutnya indeks malmquist digunakan untuk melihat tingkat produktivitas dari Rumah Zakat, baik dari sisi perubahan efisiensinya maupun perubahan teknologi.

Hasil yang diperoleh dari skor indeks produktivitas malmquist (TFP Change) menunjukkan bahwa Rumah Zakat pada tahun 2014 dan 2015 mengalami peningkatan produktivitas yang ditandai dengan skor lebih dari 1.043. Sementara sisanya menunjukkan tingkat produktivitas yang relative rendah.

\section{Analisa Efisiensi Rumah Zakat}

Berdasarkan software Banxia dapat dilihat sebagai berikut :

Tabel 4.

Tingkat Efisiensi Rumah Zakat

\begin{tabular}{cccc}
\hline Year & Score & Efficient & Condition \\
\hline 2010 & $66.10 \%$ & FALSE & Red \\
2011 & $95.30 \%$ & FALSE & Amber \\
2012 & $78.10 \%$ & FALSE & Red \\
2013 & $64.90 \%$ & FALSE & Red \\
2014 & $63.40 \%$ & FALSE & Red \\
2015 & $100.00 \%$ & TRUE & Green \\
2016 & $100.00 \%$ & TRUE & Green \\
2017 & $100.00 \%$ & TRUE & Green \\
\hline
\end{tabular}

Dari tabel tersebut diketahui

bahwa Rumah Zakat telah mencapai kondisi efisien yang ditentukan dalam 3 tahun yaitu 2015, 2016, dan 2017. Sedangkan pada tahun 2011 Rumah Zakat dalam kondisi inefficient yang berarti jika menambahkan input maka kemungkinan untuk menerima maximum output akan meningkat. Pada tahun 2010, 2012, 2013, dan 2014 Rumah Zakat mengalami kondisi yang tidak efisien dimana setiap jumlah input yang ditambahkan akan mengurangi jumlah output.

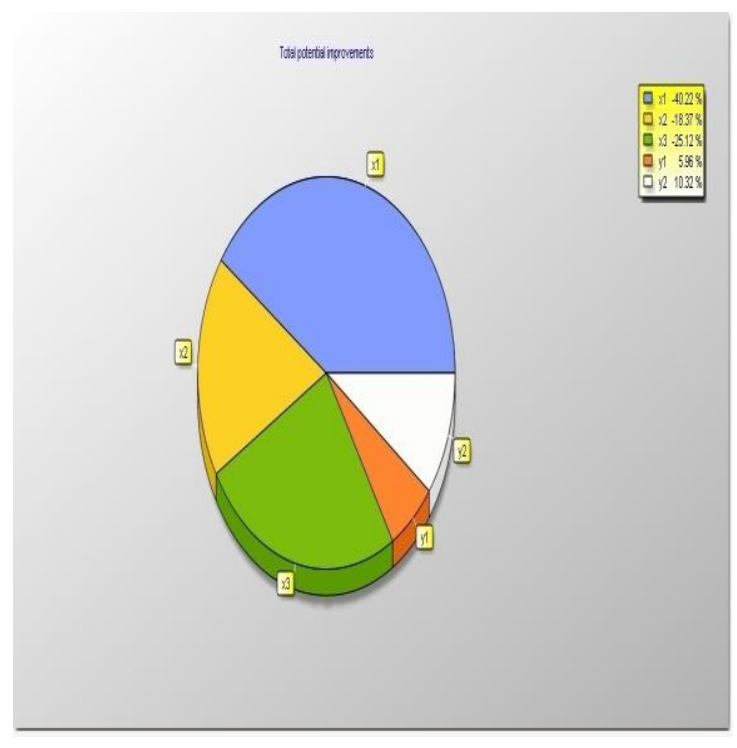

\section{Gambar 2.}

\section{Grafik Pie Chart Rumah Zakat}

Dengan memperhatikan pie chart yang merupakan hasil dari software Banxia Frontier dapat disimpulkan untuk mencapai hasil yang efisien maka Rumah Zakat harus melakukan hal berikut:

1. Rumah Zakat harus mengurangi biaya personalia sebesar $40,22 \%$

2. Rumah Zakat harus mengurangi biaya operasional sebesar $18,37 \%$

3. Rumah Zakat harus mengurangi biaya sosialisasi sebesar $25,12 \%$

4. Rumah Zakat harus meningkatkan ZISWAF yang terkumpul sebesar 5,96\%

5. Rumah Zakat harus meningkatkan ZISWAF yang tersalur sebesar 10,32 


\section{Hasil dan Pembahasan}

Penelitian ini bertujuan untuk mengetahui bagaimana efisiensi dan produktivitas Rumah Zakat Indonesia dengan menggunakan indeks malmquist. Berdasarkan data penelitihan yang didapatkan berupa laporan keuangan Rumah Zakat Indonesia dari tahun 2010 sampai dengan tahun 2017 diperoleh input dan output selama periode tersebut. Sesuai dengan metode penelitihan dan pengolahan data menggunakan Malmquist Productivity Index kemudian diperoleh hasil sebagai berikut:

a. Produktivitas Rumah Zakat Indonesia berdasarkan TFP Change mengalami tingkat produktivitas tertinggi pada tahun 2014 dan 2015 yang ditandai dengan nilai produktivitas diatas nilai mean 1,043. Tahun 2014 dengan nilai 1,051 dan tahun 2015 dengan nilai 1,373. Sementara di tahun - tahun yang lain nilai TFP Change berada di bawah nilai mean.

Hal tersebut dapat dipengaruhi oleh berbagai faktor yang ada pada Rumah Zakat Indonesia itu sendiri misalnya jumlah tenaga kerja, inovasi dan pengembangan, serta faktor faktor lain. Gambaran ini masih bersifat indikatif dan memerlukan pengujian yang formal, namun tidak tercangkup di dalam penelitihan ini.

b. Efisiensi Rumah Zakat Indonesia dari penelitian yang dilakukan menunjukkan tingkat efisiensi yang tergolong sangat baik. Pada tahun
2015, 2016, dan 2017 Rumah Zakat Indonesia memiliki nilai efisiensi 100\% walaupun pada tahun 2010 sampai 2014 masih belum efisien 100\%. Diketahui dari hasil penelitian ini ada beberapa cara agar Rumah Zakat Indonesia bisa mencapai tingkat efisiensi $100 \%$ antara lain:

1. Rumah Zakat harus mengurangi biaya personalia $40,22 \%$

2. Rumah Zakat harus mengurangi biaya operasional $18,37 \%$

3. Rumah Zakat harus mengurangi biaya sosialisasi $25,12 \%$

4. Rumah Zakat harus meningkatkan ZISWAF yang terkumpul $5,96 \%$

5. Rumah Zakat harus meningkatkan ZISWAF yang tersalur 10,32\%

c. Melihat pada hasil skor efisiensi dan produktivitas tersebut saat ini Rumah Zakat sudah memiliki berbagai macam bentuk program - program pendayagunaan dana ZISWAF yang dari tahun - ke tahun selalu mengalami peningktan yang signifikan.

\section{v. SIMPULAN}

Hasil yang diperoleh dari Malmquist Productivity Index dilihat dari skor TFP Change menunjukkan bahwa Rumah Zakat Indonesia memiliki peningkatan produktivitas dari tahun 2010 sampai 2017.Ini ditandai dengan skor lebih dari 1.000 pada tahun 2014 dan 2015.

Dalam menjalankan fungsinya sebagai organisasi pengelola zakat, efisiensi kinerja Rumah Zakat di Indonesia pada tahun awal - awal terbentuknya 
belum $100 \%$ efisien dalam melaksanakan fungsinya, tetapi seiring berjalannya waktu Rumah Zakat sekarang sudah mampu menjalankan fungsinya secara efisien. Terbukti dengan 3 tahun terakhir Rumah Zakat memiliki tingkat efisiensi $100 \%$ dan menunjukkan Rumah Zakat adalah Lembaga Amil Zakat Nasional (LAZNAS) yang kinerjanya efisien.

\section{DAFTAR PUSTAKA}

Amanda, Rica. 2010. Analisis Efisiensi Teknis Bidang Pendidikan dalam Implementasi Model Kota Layak Anak. Skripsi Universitas Diponegoro Semarang.

Anoraga, Sinungan. 2000. Manajemen Sumber Daya Manusia. Bumi Aksara. Jakarta.

Anshori, Muslich dan Sri Iswati. 2009. Metodologi Penelitihan Kuantitatif. Airlangga University Press. Surabaya.

Asili. 2017. Manajemen Strategi Filantropi Islam Di Palembang Dengan Pendekatan Appreciate Inquiry. IEconomic Vol.3 No.2

Atmanti, Hasstarini Dwi. 2005. Investasi Sumber Daya Manusia Melalui Pendidikan. Jurnal Dinamika Pembangunan. 2 (1). 30-39

Azhari, A. 2008.Kinerja Organisasi Dinas Pendapatan Daerah Provinsi Khusus Daerah Ibukota Jakarta Dengan Pendekatan System Thinking Dan System Dinamics.Disertasi tidak diterbitkan.Universitas Indonesia
Fakultas IImu Sosial dan IImu Politik Departemen IImu Administrasi Program Pasca Sarjana. Jakarta.

Bamualim, Chaider S dan Irfan Abubakar. 2005. Revitalisasi Filantropi Islam, Studi Kasis Lembaga Zakat dan Wakaf di Indonesia. Pusat Bahasa dan Budaya UIN Syarif Hidayatullah. Jakarta.

BPS Kabupaten Gresik. 2017. Sosial dan Kependudukan.

Gresik.

(https://gresikkab.bps.go.id/)

Budi, Daniel S. 2010. Efisiensi Relatif Puskesmas-Puskesmas di Kabupaten Pati Tahun 2009.Tesis.Fakultas Ekonomi Program Magister Perencanaan dan Kebijakan Publik.Universitas Indonesia. Jakarta.

Cahyono, E.F. 2017.Efficiency of Baznas (Indonesian National Zakat Amil Agency) Performance. Australian Journal of Islamic Finance and Business, Vol. 3 Issue 2 : 2206-4397

Coelli, T.J, Rao, D.S.P, Prasada Rao, Christoper J. O'Donnel and G.E Battese. 2005. Introduction to Efficiency and Productivity Analysis. (second edition). Kluwer Academic Publishers. Boston.

Dewi, Dhita Triana. 2010. Analisis Kunjungan Obyek Wisata Water Blaster Kota Semarang. Skripsi. Fakultas Ekonomi Universitas Diponegoro Semarang.

Halim, Abdul. 2004. Akuntansi Keuangan Daerah. Salemba Empat. Jakarta. 
Hasibuan, H. Malayu. 2003. Manajemen Sumber Daya Manusia. Edisi Revisi. Bumi Aksara. Jakarta.

Herjanto, Eddy. 2004. Manajemen Operasi. Edisi Ketiga. Jakarta.

Ikatan Akuntan Indonesia. 1998. PSAK No. 45 Pelaporan Keuangan Organisasi Nirlaba.

Khariza, Adhisty Mohammad. 2009. Analisis Kinerja Sektor Usaha Tani Padi Melalui Pendekatan Agribisnis. Vol. 5 No. 1

Lahutung, Brigita. 2012. Model Pengambilan Keputusan (http://model pengambilan keputusan Gita Lahutung's Blog.html, diakses tanggal 25 Februari 2018)

Mizobuchi, Hideyuki. 2015. Productivity Indexes Under Hicks Neutral Technical Change. School of Economics University of Queensland. Australia.

Qalahji, M. Rawwas. 2000. Ensiklopedi Figh Umar bin Khatab. (terjemahan $M$ Abdul Mujieb et.al). Raja Grafindo Persada. Jakarta. Dalam Saputra, AA. 2017. Makna Produktifitas Sumber Daya Manusia Ditinjau Dari Sudut Pandang Syariah Dan Konvensional. Stie Indocakti Malang.

Rakhmadi, Rezki Syahri. 2010. Analisis Efisiensi Produktivitas Perbankan Syariah Indonesia. Fakultas Ekonomi dan Bisnis Universitas Islam Negeri Syarif Hidayatullah. Jakarta.
Raphael, G. 2013. A DEA Based Malmquist Productivity Index Approach in Assessing Performance of Commercial Banks: Evidence From Tanzania. Europian journal of bussness and management. Vol. 5 No. 6 pp $25-34$

Republik Indonesia. Undang-undang Republik Indonesia Nomor 23 tahun 2011 tentang pengelolaan zakat.2012. Biro Bina Mental dan Kesra. Jakarta.

Rusydiana, AS. 2015. Indeks Malmquist Untuk Pengukuran Efisiensi dan Produktivitas Bank Syariah di Indonesia.

Saleh, Samsubar. 2000. Metode Data Envelopment Analysis. Yogyakarta. PAU-FE Universitas Gadjah Mada.

Saputra, AA. 2017. Makna Produktifitas Sumber Daya Manusia Ditinjau Dari Sudut Pandang Syariah Dan Konvensional. Stie Indocakti Malang.

Soekarwati. 1989. Prinsip Dasar Ekonomi Pertanian. Rajawali Press. Jakarta. Dalam Rendiana, Gery. 2015. Analisis Pengaruh Efisiensi (BOPO) Dan Capital Adequacy Ratio (CAR) Terhadap Return On Assets (ROA) (Study Kasus Pada Perbankan Syariah Yang Terdaftar Di OJK Pada Tahun 2010 - 2014).

Sugiyono. 2009. Metode Penelitian Kuantitatif, Kualitatif dan R\&D. Alfabeta. Bandung. 
Sunarto. 2010. Pengantar Statistika (Untuk

Penelitian Pendidikan Sosial,

Komunikasi, Ekonomi dan Bisnis).

Alfabeta. Bandung.

Supomo, Bambang dan Nur Indriantoro. 2003. Metodologi Penelitihan Bisnis. Cetakan Kedua. BFEE UGM. Yogyakarta.

Talluri, S. 2000. Data Envelopment Analysis: Models and Extension. Decision Line 31 (3): 8-11

Yaumidin, U.K. 2007. EfficienyIn Islamic Banking, A non-parametic Approach. Buletin Economi Moneter dan Perbankan. Apri 2007

Yildirim, I. 2015. Financial efficiency analysis in Islamic banks: Turkey and Malaysia models. Journal of Economics, Finance, and Acounting Vol. 2, Issues 3. Pp 289300

Yudistira, Donsyah. 2003. Efficiency in Islamic Banking: an Empirical Analysis of 18 Banks. Proceding International Conference o Islamic Banking: Risk Management, Regulation, and Supervision. Bank Indonesia, $\quad 30 \quad$ September-2 Oktober 2003. Bank Indonesia. Jakarta.

Zhang, B. 2013.Integrated systems approach identifies genetic nodes and networks in late-onset Alzheimer's disease. US National Library of Medicine National Institutes of Health. Bethesda. 